\title{
Research on Financial Openness and Regulation
}

\author{
YudongHou \\ School of Economics, Wuhan University of Technology, Wuhan 430070, China
}

Keywords:finance, financial openness, regulation.

\begin{abstract}
With China's accession to WTO, China's opening-up goes further. Inevitably, the financial sector and international financial changes become more and more relevant which makes the financial openness go deeper. When changes in the global financial happen, itself will also be affected. Therefore, this paper studies the regulation under financial opening-up.
\end{abstract}

\section{Introduction}

In the tide of economic and financial globalization, any country wants to share the world gains in economic development and cooperation, it must be integrated into the process of economic globalization. However, the increasing integration of the world economy makes the risks to the countries in the "global village" become complex and widespread. Therefore, an open economy will have to face challenges and threats from the outside world risk at the same time. Since reform and opening up began in in the late 1970s, the openness of China's national economy has increased rapidly. Open domain extends from coastal to inland and open industry expands from the real economy to the financial sector. At the beginning of the reform and opening up, China's opening-up mainly focused on real economy which leads to the rapid development of external trade. In the financial field, the use of foreign capital was vigorously promoted absorbing a large amount of foreign direct investment. A large number of loansis received from foreign governments, international financial institutions and international financial markets. Domestic financial markets are also beginning to develop steadily and rapidly.

In order to meet the needs of financial innovations and financial development, a number of countries focused on harmonization of regulatory standards and beganto reduce duplication. It makes financial regulatory system change from decentralization to consolidation. In Norway, Denmark and Sweden, due to the financial innovations and financial development, particularly the emergence of financial holding group, it makes financial regulatory system change from decentralization to consolidation. The financial regulatory system is mainly responsible for banking, securities and insurance businesses. Table 1 shows the financial regulatory system in different countries. Looking to the future prospects of the financial regulatory system, it can be seen that financial regulation trend will be centralized and unitized.

Table 1 financial regulatory system in different countries

\begin{tabular}{cc}
\hline Regulatory Forms & Number of countries \\
\hline Sector Regulation & 34 \\
Integrated Regulation & 39 \\
Security and Insurance & 3 \\
Banking and Security & 9 \\
Banking and Insurance & 13 \\
Triad & 14 \\
\hline
\end{tabular}

\section{Research Significance}

In the tide of financial globalization, China's banks are facing an increasingly open market environment. In December 2006 marked by the full opening of bank, the bank has entered a new stage of development in China, and it has been actively transformingunder the new competition. Compared with the past, the bank at this stage has a lot of new features, which involves a broader, potentially riskier. Deep-seated contradictions have become more prominent. Hence, the Chinese government 
has taken measures to cope with the problems. The coordination of financial regulation needs to enhance.It is necessary to establish and improve financial risk early-warning system and management mechanism. The stability of the banking system is the core of China's financial stability. Under the prerequisite of ensuring financial stability, it can be a challenge to promote financial reforms for China.China has traditionally dominated by indirect financial and banks in the financial system saddled with heavier tasks than the developed countries.Not only in terms of resource allocation and payment channels it plays a key role, but in the whole economic system reform. From this point of view, the opening to the Bank under the condition of efficiency, stability, control and financial security issues is related to the stable and healthy development of economy and society. Therefore, further research on these issues have important practical significance.How to establish and perfect financial monitoring system plays an important role in the development of China's economy.

\section{Effective Financial Supervision Mechanism}

\subsection{Realization of Functional Financial Supervision}

In the context of financial liberalization and globalization of international, mixed operation has become a global trend of financial industry development. If the government still insists on separate operation in China, not only the security of the financial system cannot be able to maintain, but it will risk losing the efficiency of the financial system, bounding the development of China's financial industry. Therefore, removing artificial restrictions and creating equal competitive environment for domestic financial institutions is the inevitable choice for China's financial reform. If the financial industry is going to conduct mixed operation, the existing financial supervision system must be reformed replacing the traditional regulatory system with functional financial supervision system.

\subsection{Perfect Internal Control Mechanism for Financial Institutions}

The internal control of financial institutions is the basis of modern financial supervision. With a good and strict internal control, the external financial regulation can be effective. Because as a financial innovation of financial institutions, in order to chase profits and evade financial regulation, it will create a new financial product or financial instruments, however, the financial regulatory supervision and regulation have lags. In order to avoid the formation of self-innovation and financial risk by financial institutions, and strengthening the internal control of financial institutions becomes the basis and premise of implementing effective financial supervision.During the process of establishingthe internal control mechanism of China's financial institutions, the most important thing is the perfection of the internal control mechanism in commercial banks. Establishment and perfection of internal control system of commercial banks must obey the country's laws, regulations and regulatory requirements of the financial regulator, ensuring that the various risk control or lower within the specified range, in order to achieve their goal of development strategy.

\subsection{Regulation of Financial Industry Self-regulatory Organization}

Effective financial regulation needs the joint efforts from all aspects. Through the establishment of financial industry self-regulatory organizations, it can urge all members of financial institutions to implement state financial laws and regulations, and coordinate financial institutions competition which can ensure stable and healthy development of the financial industry. Meanwhile, it will also serve to further promotionof China's opening up in the financial sector and its participation in international market competition can be well organized. In recent years, under the guidance of the Central Bank, many regions in China have established local self-regulatory organizations. Under the financial integrated and market oriented environment, competitions between the financial sectors become severe. China's securities industry and the insurance industry are also trying to establish self-discipline organizations. With the establishment and improvement of financial industry self-regulatory organizations, problems in the financial institutions in their day-to-day business operations can be resolved by financial industry associations in accordance with market rules to ensure healthy competition among financial institutions. Figure 1 shows the concept of self-regulatory organization. 


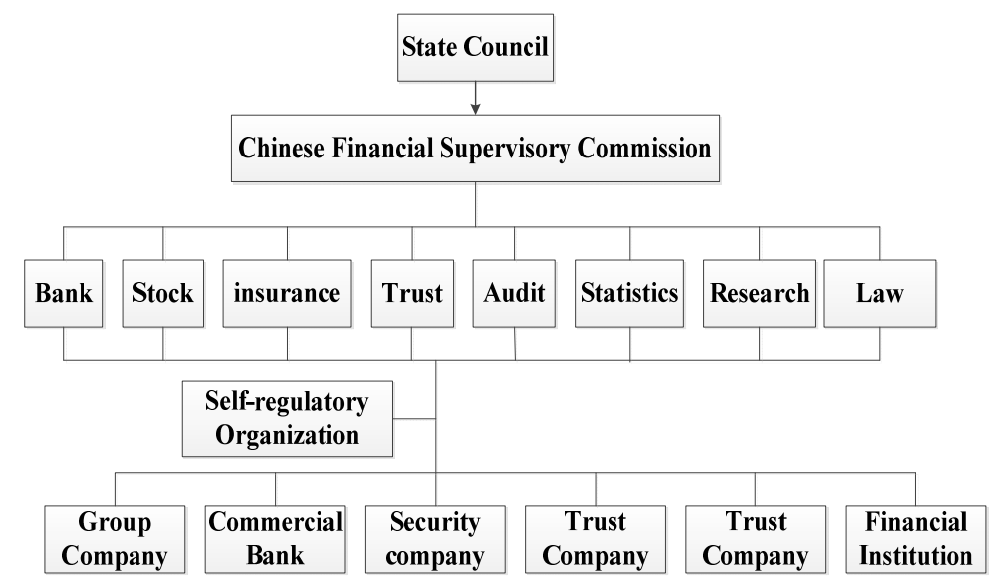

\subsection{Strengthen Financial Law}

Fig.1 Concept of Self-regulatory Organization

Financial laws and regulations are the legal basis to ensure the implementation of the financial regulation and financial security. Also, it is the legal guarantee for the standardization and legalization of financial supervision. In recent years, China has promulgated a number of laws and regulations which play an important role in practice. After joining the WTO, China has promulgated a number of laws and regulations. These regulations is very important for the maintenance of social stability and the country's financial security. And it is very helpful for the development of financial industry. Meanwhile, financial law enforcement should be strengthened.Giving the corresponding powers and keeping its operational independence, better safeguard economic and financial order can be obtained. In addition, existing financial laws, regulations and regulatory documents should be cleaned, in order to avoid conflict and contradiction which may lead to regulatory chaos.

\section{Summary}

In short, in order to adapt to the advancement of the accession to the WTO and financial opening-up, we will stand at the forefront of the times and historical perspective to achieve the mission of national interest and national development goals. A financial supervision system should be built to adapt to the establishment and modernization of financial openness. Practically, specific programof establishment of Chinese Financial Supervisory Commission should be taken into consideration. It can achieve the integration of regulatory functions and prevent sectional interests which will lead to the healthy development of national economy.

\section{References}

[1]. Xiaoan Qian. Conception of Establishing Unified Financial Supervision System in China, Finance \& Economic, Vol. 2 (2002), pp.6-12.

[2]. Zili Wang. Re-discussion on Chinese Financial Supervision System and Supervision, Journal of Finance, Vol. 12 (2000), pp.79-85.

[3]. XinshuangZi. Research on China's financial opening, Business Research, Vol. 22 (2012), pp. 173-175.

[4]. Yuanlong Wang. Study on Problems of Financial Security in China's Opening-up, Studies of International Finance, Vol. 5 (1998), pp. 33-39.

[5]. Yuanlong Wang, Lingyan Jin, Huijie Liao, et al. China's Financial Opening: History, Challenges and Countermeasures, Review of Economic Research, Vol. 4 (2009), pp. 2-44.

[6]. Zhenyou Yang, XihongHou. Innovation and Effective Supervision in the Course of Opening up China.s Financial Sector, Journal of ShanXi Finance and EconomicsUniversity, Vol. 24 (2002) No. 5, pp. 68-71. 